DOI 10.31558/2307-2318.2021.4.23

УДК $339.97+519.237 .8$

JEL C 10; C 40; F 29; O 33; O 47; O 50

Таранич А. В.,

к.е.н., доцент, доцент кафедри маркетингу,

Донецький національний університет імені Василя Стуса,

ORCID: 0000-0003-0309-6100

a.taranych@donnu.edu.ua

Таранич О. В.,

к.е.н., доцент, доцент кафедри менеджменту та поведінкової економіки, Донецький національний університет імені Василя Стуса,

ORCID: 0000-0002-7859-8706

o.taranych@donnu.edu.ua

\title{
ОЦІНКА ТА ПОРІВНЯННЯ МІЖНАРОДНОЇ КОНКУРЕНТОСПРОМОЖНОСТІ КРАЇН
}

В роботі розкрито особливості визначення міжнародної конкурентоспроможності країн у світових рейтингах й оцінено результати їх рейтингування.

Проведено оцінку рейтингів міжнародної конкурентоспроможності країн за період з 2005 до 2019 рр., яка дозволила визначити, щзо вони дають співставні результати, щуо відображають наявний $i$ перспективний потенціал національних економік. Визначено, що ЄС як значне інтеграційне утворення у світовій економіці посилює позииії на світовому ринку як провідних його учасників, так $і$ незалежних економік, які орієнтуються на нього як найбільший регіональний ринок у світі; $з$ іншого боку, середні та слабкі за економічним розвитком країни-учасники $Є С$ не посилили власних позищій у рейтингах, щэо залишає актуальним питання до пошуку шляхів їх подальшого зростання.

Проведено кластерний аналіз за різним набором показників, щзо показав сталу карту розподілу країн по п'яти кластерах, які визначаються ступенем їх економічного розвитку. При суміщенні двох рейтингів міжнародної конкурентоспроможності крайн визначено, що вони відображають тісний зв'язок між ними (географічна подібність) й економічними стратегіями (потрапляння до одного сегменту у межах кластеру, наприклад, краӥни-експортери нафти; міста-краӥни; малі країни-острови; краӥни з найбільшими економіками у світі; скандинавські краӥни; прибалтійські краӥни). За результатами кластерного аналізу визначено збіг розподілу країн за територіальною й економічною подібністю, сутність якого полягає в тому, щуо країни-сусіди мають схожі географічні умови та реалізують стратегії економічного розвитку, орієнтуючись одна на одну, тобто територіальний чинник має важливе значення при формуванні міжнародної конкурентоспроможності країн. Другим фактором подібності є стратегії економічного розвитку країн.

Ключові слова: міжнародна конкурентоспроможність краӥн, світові рейтинги конкурентоспроможності, світове господарство, кластерний аналіз, COVID-19.

Рис. 5 , табл. 7 , літ. 2 
Постановка проблеми. Глобалізаційний розвиток світового господарства поглибив економічну диференціацію та посилив відрив розвинених економік від тих, що розвиваються. За цих умовах визначення чинників зростання міжнародної конкурентоспроможності країн $є$ імперативом державної політики, орієнтованої на поглиблення їх міжнародного поділу праці, розвиток перспективних економічних інтересів.

Мета роботи - розкрити особливості визначення міжнародної конкурентоспроможності країн у світових рейтингах й оцінити результати їх рейтингування.

Аналіз досліджень і публікацій. Питання міжнародної конкурентоспроможності країн визначено в роботах Й. Шумпетера, Г. Хамела, А. Чандлера, I. Ансоффа, М. Енрайта, Б. Карлофа, П. Дойля, К. Кодзимі, П. Кругмана, Д. Мінцберга, Ж.-Ж. Ламбена, М.Портера, К. Прохалада, Д. Моррісона, А. Сливоцького; так і українських дослідників Л.Антонюк, Я. Базилюка, Я. Белинської, Б. Губського, Я. Жаліла, Ю. Козака, І. Д.Лук'яненка, Сіваченка, О. Павловської, А.Поручника, Ю. Сханурова.

Основні методики оцінки міжнародної конкурентоспроможності використовуються Всесвітнім економічним форумом у Давосі (World Economic Forum ВЕФ, [1]), що координуються професором М. Портером, та Інститутом розвитку менеджменту в Лозанні («International Institute for Management Development» - IMDLausanne, [2]). Це приблизно аналогічні методики визначення рейтингу країни в списку найбільш конкурентоспроможних економік світу. За деяких незначних відмінностей у методології, суть цих двох підходів зводиться до вимірювання та ранжирування окремих груп показників розвитку країн; і виведення синтетичного показника їх конкурентоспроможності.

ВЕФ для розрахунку індексу глобальної конкурентоспроможності (Global Competitiveness Index, GCI) використовує багатофакторні векторні моделі, у свою чергу цей індекс складається з індексів макроекономічного середовища, публічних інституцій та технологій (рис. 1).

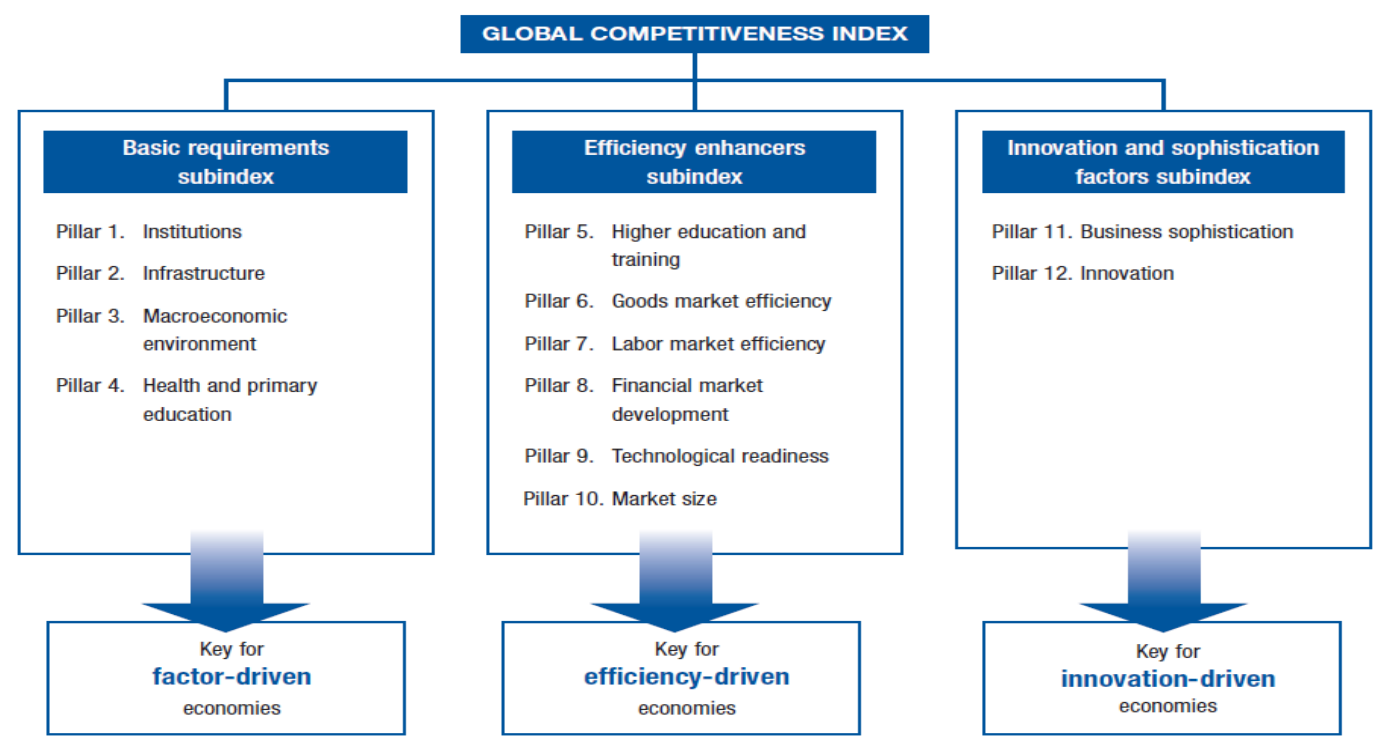

Рисунок 1. Складові Індексу глобальної конкурентоспроможності країн ВЕФ Джерело: ВЕФ: https://www.weforum.org/reports/ the-global-competitiveness-report 
Результати. Відповідно, базові вимоги складаються 3 чотирьох стержневих компетенцій, які формують ключові індикатори для факторно-залежних економік. Сутність залежності національних економік від ресурсних факторів, факторів ефективності й інновацій визначається обсягами ВВП на душу населення, які утворюють розподіл країн на п’ять категорій: три базових (див. рис. 1) і дві перехідних, граничні межі яких складає рівень питомого ВВП у розмірі 2, 39 і 17 тис долл. США. Також для кожної групи країн за рівнем економічного розвитку змінюється співвідношення питомих ваг у розподілі базових субіндексів, які зменшуються з 60 до $20 \%$ для більш розвинених категорій країн; вага для субіндексу, що відображає підсилення ефективності, зростає 335 до 50 \%; вага для факторів інноваційності та досвідченості зростає з 5 до $30 \%$.

Субіндекс, що відображає підсилення ефективності, складається 3 шести стержневих компетенцій; i субіндекс, що відображає фактори інноваційності та досвідченості, складається з цих двох зазначених стержневих компетенцій.

Відповідно до розподілу країн за категоріями ВВП на душу населення, наведених на рис. 2.2, за період з 1970 до 2020 рр., окремі розвинені країни досягають рівня 70-100 тис. долл. США за цим показником (Люксембург, Бермудські острови, Швейцарія, Ліхтенштейн, Кайманові острови, Ірландія, Норвегія). Середній рівень припадає на промислово-розвинені країни та розвинені регіони (35-40 тис. долл. США): Німеччина, Ізраїль, Бельгія, Канада, Нова Зеландія, Об'єднане Королівство, Японія, Франція, Об'єднані Арабські Емірати. Проміжний рівень вище середнього (45-65 тис. долл. США) мають такі країни, як: Сполучені Штати Америки, Ісландія, Данія, Сінгапур, Швеція, Нідерланди, Австралія, Катар, Фінляндія, Австрія, Гонконг.

Середньосвітове значення питомого ВВП з 2011 до 2020 рр. складає 10,7 тис. дол. США (в 2018/19 рр. максимум становив 11,3 тис. дол. США), що відповідає показникам таких країн, як Китай, РФ, Болгарія.

Регіони, що розвиваються, досягли на кінець аналізованого періоду (з 2017 р.) середнього значення 5,3 тис. дол. США. Розподіл загальної кількості країн за результатами 2020 р. наведено у табл. 2.1. За оцінками ВЕФ, Україна є у числі країн, які знаходяться на другій стадії економічного зростання, розвиток i конкурентоспроможність яких базується на ресурсних факторах, і в яких обсяг ВВП на душу населення становить від 2000 до 2999 дол США. (Україна тричі подолала межу 3000 дол. США / на душу населення за підсумками 2007/08 pp, 2011-2013 pp. і 2019/20 pp.).

У звіті зазначено, що конкурентоспроможність визначається як рівень продуктивності країни, який потім визначає рівень достатку, що продукується національною економікою, та рівень прибутку, який одержує бізнес, у тому числі за рахунок інвестицій. Разом, продуктивність й інвестиції $\epsilon$ двигунами зростання національних економік, відповідно, більш конкурентоспроможна економіка дозволяє підтримувати більш стійке економічне зростання.

В такому трактуванні конкурентоспроможність країни складається зі статичних i динамічних компонент, з яких перша визначає здатність підтримувати високий рівень доходів (сталий розвиток), а друга дозволяє залучати додаткові інвестиції на стабільній основі, що пояснює потенціал зростання національних економік протягом всього аналізованого періоду. 


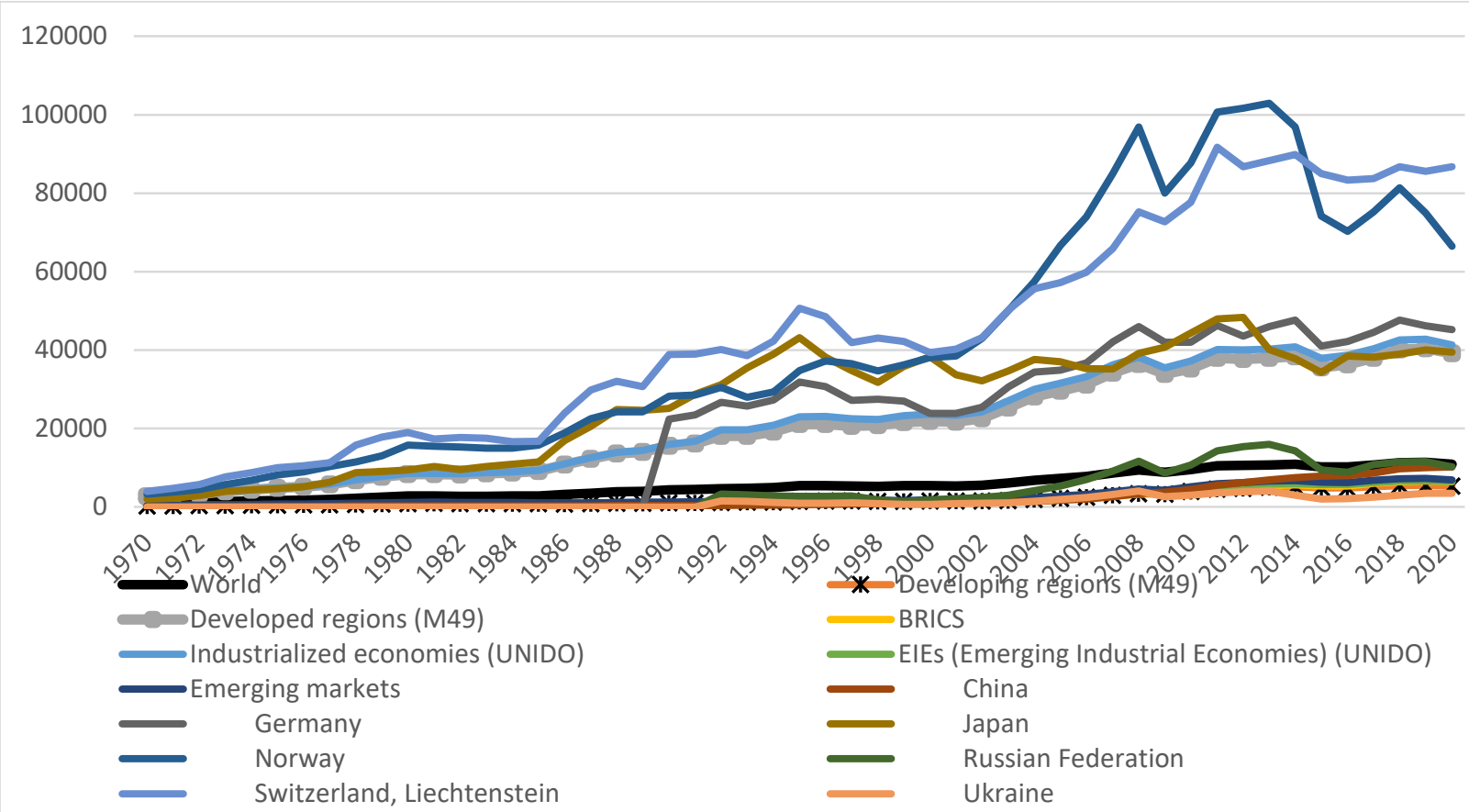

Рисунок 2. Динаміка ВВП на душу населення за різними категоріями країн за період з 1970 до 2020 рр., долл. США

Джерело: складено авторами за даними https://unctadstat.unctad.org/

Таблиця 1

Порогові значення ВВП на душу населення (дол. США) при розрахунках індексу глобальної конкурентоспроможності країн ВЕФ для 2020 р.

\begin{tabular}{|c|c|c|c|c|c|}
\hline Показники & $<2000$ & $2000-2999$ & $3000-8999$ & $9000-17000$ & $>17000$ \\
\hline $\begin{array}{l}\text { Фактори } \\
\text { розвитку } \\
\text { країн }\end{array}$ & $\begin{array}{c}\text { Етап 1: } \\
\text { факторно- } \\
\text { орієнтовані } \\
\text { країни }\end{array}$ & $\begin{array}{c}\text { Перехід від } \\
\text { етапу } 1 \text { до } \\
\text { етапу } 2\end{array}$ & $\begin{array}{c}\text { Етап 2: } \\
\text { орієнтовані } \\
\text { на } \\
\text { ефективність }\end{array}$ & $\begin{array}{c}\text { Перехід від } \\
\text { етапу } 2 \text { до } \\
\text { етапу } 3\end{array}$ & $\begin{array}{c}\text { Етап 3: } \\
\text { орієнтовані } \\
\text { на інновації }\end{array}$ \\
\hline $\begin{array}{l}\text { Кількість } \\
\text { країн }\end{array}$ & 52 & 11 & 61 & 25 & 57 \\
\hline
\end{tabular}

Джерело: складено авторами за даними https://unctadstat.unctad.org/

У табл. 2 наведено порівняння позицій 13 країн у період з 2005 до 2019 рр. за рейтингом їх міжнародної конкурентоспроможності за методикою ВЕФ, яка показує тривале лідерство США протягом всього аналізованого періоду, за виключенням наслідків світової кризи 32009 до 2012 рр., а також нових індустріальних країн (Сінгапур i Гонконг), та інших високорозвинених країн світу, особливо північноєвропейських, на відміну від південноєвропейських, які посідають 15-30 місця (наприклад, Франція), Іспанія (23 місце), Італія (30 місце), Туреччина (61 місце).

Рейтинг IMD визначає, наскільки соціальне середовище сприяє підвищенню конкурентоспроможності країни - враховуються бізнес-атмосфера, економічні i соціальні показники країн. Для обліку такого чинника, як атмосфера для розвитку бізнесу, IMD була розроблена спеціальна методика - крім статистичних даних, у кінцевому рейтингу знаходять віддзеркалення думки і настрої представників бізнеселіти досліджуваних країн. 
Таблиця 2

Рейтинг міжнародної конкурентоспроможності країн світу за методикою ВЕФ (Тhe

Global Competitiveness Report), [1]

\begin{tabular}{|l|c|c|c|c|c|c|c|c|c|c|c|c|c|c|c|}
\hline \multicolumn{1}{|c|}{ Країни } & 2005 & 2006 & 2007 & 2008 & 2009 & 2010 & 2011 & 2012 & 2013 & 2014 & 2015 & 2016 & 2017 & 2018 & 2019 \\
\hline $\begin{array}{l}\text { Загальна } \\
\text { кількість } \\
\text { країн }\end{array}$ & $\mathbf{1 1 7}$ & $\mathbf{1 2 5}$ & $\mathbf{1 3 1}$ & $\mathbf{1 3 4}$ & $\mathbf{1 3 3}$ & $\mathbf{1 3 9}$ & $\mathbf{1 4 2}$ & $\mathbf{1 4 4}$ & $\mathbf{1 4 8}$ & $\mathbf{1 4 4}$ & $\mathbf{1 4 0}$ & $\mathbf{1 3 8}$ & $\mathbf{1 3 7}$ & $\mathbf{1 4 0}$ & $\mathbf{1 4 1}$ \\
\hline Сінгапур & 6 & 5 & 7 & 5 & 3 & 3 & 2 & 2 & 2 & 2 & 2 & 2 & 3 & 2 & 1 \\
\hline США & 2 & 1 & 1 & 1 & 2 & 4 & 5 & 7 & 5 & 3 & 3 & 3 & 2 & 1 & 2 \\
\hline Гонконг & 28 & 11 & 12 & 11 & 11 & 11 & 11 & 9 & 7 & 7 & 7 & 9 & 6 & 7 & 3 \\
\hline Швейцарія & 8 & 6 & 2 & 2 & 1 & 1 & 1 & 1 & 1 & 1 & 1 & 1 & 1 & 4 & 5 \\
\hline Японія & 12 & 7 & 8 & 9 & 8 & 6 & 9 & 10 & 9 & 6 & 6 & 8 & 9 & 5 & 6 \\
\hline Німеччина & 15 & 8 & 5 & 7 & 7 & 5 & 6 & 6 & 4 & 5 & 4 & 5 & 5 & 3 & 7 \\
\hline Швеція & 3 & 3 & 4 & 4 & 4 & 2 & 3 & 4 & 6 & 10 & 9 & 6 & 7 & 9 & 8 \\
\hline Данія & 4 & 4 & 3 & 3 & 5 & 9 & 8 & 12 & 15 & 13 & 12 & 12 & 12 & 10 & 10 \\
\hline Фінляндія & 1 & 2 & 6 & 6 & 6 & 7 & 4 & 3 & 3 & 4 & 8 & 10 & 10 & 11 & 11 \\
\hline Франція & 30 & 18 & 18 & 16 & 16 & 15 & 18 & 21 & 23 & 23 & 22 & 21 & 22 & 17 & 15 \\
\hline Китай & 49 & 54 & 34 & 30 & 29 & 27 & 26 & 29 & 29 & 28 & 28 & 28 & 27 & 28 & 28 \\
\hline Росія & 75 & 62 & 58 & 51 & 63 & 63 & 66 & 67 & 64 & 53 & 45 & 43 & 38 & 43 & 43 \\
\hline Україна & $\mathbf{8 4}$ & $\mathbf{7 8}$ & $\mathbf{7 3}$ & $\mathbf{7 2}$ & $\mathbf{8 2}$ & $\mathbf{8 9}$ & $\mathbf{8 2}$ & $\mathbf{7 3}$ & $\mathbf{8 4}$ & $\mathbf{7 6}$ & $\mathbf{7 9}$ & $\mathbf{8 5}$ & $\mathbf{8 1}$ & $\mathbf{8 3}$ & $\mathbf{8 5}$ \\
\hline
\end{tabular}

Джерело: складено авторами за матеріалами ВЕФ: https://www.weforum.org/reports/ theglobal-competitiveness-report

У річному звіті про конкурентоспроможність (World Competitiveness Yearbook [2]) з 1989 року IMD відображено 57 країн, що відіграють ключові ролі в світовій економіці. 3 них 29 є членами Організації Економічного Співробітництва і Розвитку (ОЕСР), а також входять до складу СС, 6 - Нові індустріальні країни, останні найбільш великі економіки, що розвиваються. Так, з пострадянських країн в рейтингу тільки Росія та Україна (з 2007 року), зі всіх країн Африки - Південна Африка, з країн західної Азії - Ізраїль, Йорданія і Туреччина, з Східної Азії - Китай та Індія, 3 Латинської Америки - Аргентина, Бразилія, Венесуела, Колумбія, Мексика, Чилі.

За індексом IMD, розрахованим для періоду 2015-2021 pр., Україна займає 54 місце 364 країн (табл. 3) (у 2015 р. - 60 місце з 61 країн, у 2016 р. - 59 місце 361 країни, у 2020 р. - 55 місце 3 64).

Таблиця 3

Рейтинг міжнародної конкурентоспроможності країн світу за методикою IMD (WORLD COMPETITIVENESS YEARBOOK), [2]

\begin{tabular}{|l|c|c|c|c|c|}
\hline Країни & 2015 & 2016 & 2017 & 2018 & 2019 \\
\hline Singapore & 3 & 4 & 3 & 3 & 1 \\
\hline Hong Kong & 2 & 1 & 1 & 2 & 2 \\
\hline USA & 1 & 3 & 4 & 1 & 3 \\
\hline Switzerland & 4 & 2 & 2 & 5 & 4 \\
\hline United Arab Emirates & 12 & 15 & 10 & 7 & 5 \\
\hline Netherlands & 15 & 8 & 5 & 4 & 6 \\
\hline Ireland & 16 & 7 & 6 & 12 & 7 \\
\hline Denmark & 8 & 6 & 7 & 6 & 8 \\
\hline Sweden & 9 & 5 & 9 & 9 & 9 \\
\hline Qatar & 13 & 13 & 17 & 14 & 10 \\
\hline Norway & 7 & 9 & 11 & 8 & 11 \\
\hline Luxembourg & 6 & 11 & 8 & 11 & 12 \\
\hline Canada & 5 & 10 & 12 & 10 & 13 \\
\hline
\end{tabular}




\begin{tabular}{|l|l|l|l|l|l|}
\hline China & 22 & 25 & 18 & 13 & 14 \\
\hline Finland & 20 & 20 & 15 & 16 & 15 \\
\hline Germany & 10 & 12 & 13 & 15 & 17 \\
\hline Australia & 18 & 17 & 21 & 19 & 18 \\
\hline Iceland & 24 & 23 & 20 & 24 & 20 \\
\hline Russian Federation & 45 & 44 & 46 & 45 & 45 \\
\hline Ukraine & 60 & 59 & 60 & 59 & 54 \\
\hline
\end{tabular}

Джерело: складено авторами за матеріалами IMD

Порівняння результатів рейтингів ВЕФ і ІМД свідчить про приблизно однакові позиції країн, з невеликим коливаннями. Спільні позиції у рейтингах належать містамдержавам Сінгапур і Гонконг, найбільшим країнам у світі США, Канаді, Австралії, країнам $\mathrm{CC}$, у першу чергу північним і скандинавським, а також тим, що не входять до складу СС - Швейцарія (2-5 місця в рейтингу IМД) і Норвегія (7-11 місця). Однією 3 відмінностей рейтингів $є$ позиція Китаю, вища за розрахунками IMД (22-13 місця), ніж ВЕФ (54-27 місця відповідно). Позиції України є більш низькими в розрахунках ВЕФ (85-72 місця) за рахунок більшої кількості країн і відмінностях у методиці визначення рейтингових позицій.

За даними, що визначають субфактори конкурентоспроможності країн за розрахунками ВЕФ і ІМД побудуємо дендрограму як результат кластерного аналізу (рис. 3).

На ii підставі ми можемо розділити досліджені країни на 2-5 кластерів в залежності від ступеня укрупнення: 2 кластери на максимальній дистанції зчеплення (з'єднання), 3 кластери на відстані 300 одиниць, 4 кластери на відстані 200 одиниць і 5 кластерів на відстані 150 одиниць (табл. 4).

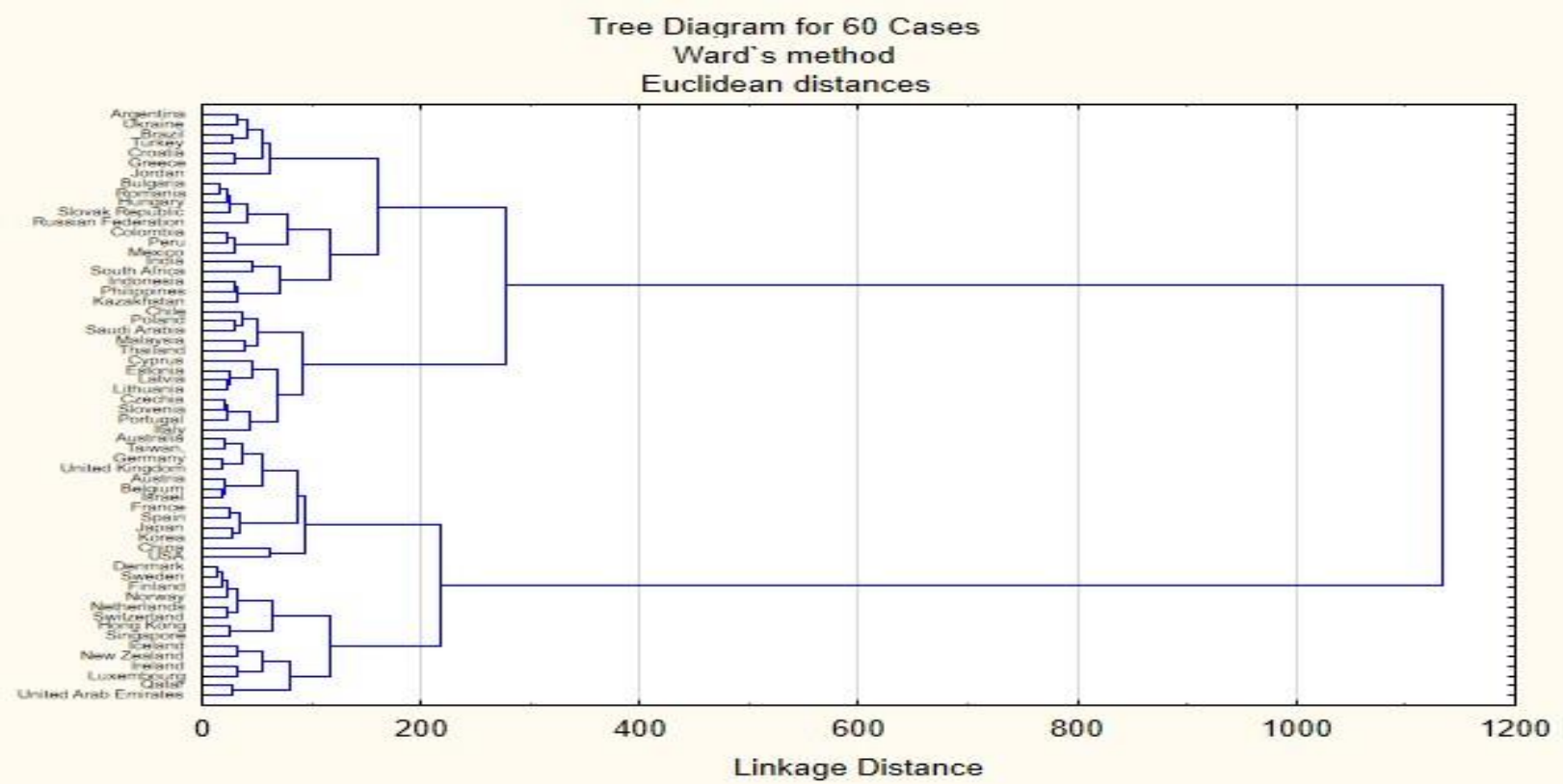

Рисунок 3. Дендрограма кластерного аналізу 60 країн світу

Джерело: розраховано авторами

Суміщення двох рейтингів свідчить, що вони відображають тісний зв'язок між країнами (географічна подібність) й економічними стратегіями (потрапляння до одного сегменту у межах кластеру, наприклад, країни-експортери нафти; міста-країни; малі 
країни-острови; країни з найбільшими економіками у світі; скандинавські країни; прибалтійські країни).

Таблиця 4

Розподіл країн на кластери

\begin{tabular}{|l|l|l|}
\hline Кластери & Сегменти & Країни \\
\hline Кластер 1 & 1 & United Arab Emirates, Qatar, \\
& 2 & Luxembourg, Ireland, New Zealand, Iceland \\
& 3 & Singapore, Hong Kong \\
& 4 & Switzerland, Netherlands, Norway, Finland, Sweden, Denmark \\
\hline Кластер 2 & 1 & USA, China \\
& 2 & Korea, Japan \\
& 3 & Spain, France \\
& 4 & Israel, Belgium, Austria \\
& 5 & United Kingdom, Germany \\
\hline Кластер 3 & 1 & Taiwan, Australia \\
& 2 & Portugal, Slovenia, Czechia, Italy \\
& 3 & Lithuania, Latvia, Estonia, Cyprus \\
& 4 & Thailand, Malaysia \\
\hline Кластер 4 & 1 & Saudi Arabia, Poland, Chile \\
& 2 & Kazakhstan, Philippines, Indonesia \\
& 3 & Mexth Africa, India \\
& 4 & Russian Feru, Colombia \\
\hline Кластер 5 & 1 & Jordan \\
& 2 & Greece, Croatia \\
& 3 & Turkey, Brazil \\
& 4 & Ukraine, Argentina \\
\hline
\end{tabular}

Джерело: розраховано авторами

Кластери 1 і 2 представлені високорозвиненими країнами світу, більшість з яких входить до об'єднання G-20. Однією з особливостей розподілу є розташування США і Китаю в одному сегменті за спільністю ознак, хоча за результуючими показниками останній відноситься до країн із середнім рівнем конкурентоспроможності.

Кластер 3 представлений південними та східними країнами $\mathrm{CC}$, включаючи прибалтійські, а також розвиненими індустріальними країнами Азії. Кластери 4 і 5 представлені країнами, які мали статус транзитивних, а в теперішній час характеризуються активним індустріальним розвитком. Відповідно, Україна має одну $з$ слабких позицій у рейтингах, і завершує ранжування, разом із Аргентиною в одному сегменті.

Щоб визначити профілі кластерів, проведемо додатковий аналіз методом Ксередніх із визначеною кількістю кластерів 4 і 5 (табл. 5 і табл. 6).

Таблиця 5

Розподіл країн на 4 кластери методом К-середніх

\begin{tabular}{|c|c|c|c|}
\hline $\begin{array}{l}\text { Members of Cluster } \\
\text { Number } 1\end{array}$ & $\begin{array}{c}\text { Members of Cluster Number } \\
2\end{array}$ & $\begin{array}{l}\text { Members of Cluster } \\
\text { Number } 3\end{array}$ & $\begin{array}{l}\text { Members of Cluster } \\
\text { Number } 4\end{array}$ \\
\hline $\begin{array}{l}\text { Chile, } \\
\text { Czechia, Estonia, } \\
\text { Indonesia, } \\
\text { Kazakhstan, Latvia, } \\
\text { Lithuania, } \\
\text { Portugal, } \\
\text { Arabia, Soland, } \\
\text { Thailand }\end{array}$ & $\begin{array}{l}\text { Argentina, Brazil, Bulgaria, } \\
\text { Colombia, Croatia, Greece, } \\
\text { Hungary, India, Jordan, } \\
\text { Mexico, Peru, Philippines, } \\
\text { Romania, } \\
\text { Federation, Slovak Republic, } \\
\text { South Africa, Turkey, } \\
\text { Ukraine }\end{array}$ & $\begin{array}{l}\text { Denmark, Finland, Hong } \\
\text { Kong, Iceland, Ireland, } \\
\text { Luxembourg, } \\
\text { Netherlands, New } \\
\text { Zealand, Norway, Qatar, } \\
\text { Singapore, Sweden, } \\
\text { Switzerland, Taiwan, } \\
\text { United Arab Emirates }\end{array}$ & $\begin{array}{l}\text { Australia, Austria, } \\
\text { Belgium, China, France, } \\
\text { Germany, Israel, Japan, } \\
\text { Korea, Malaysia, Spain, } \\
\text { United Kingdom, USA }\end{array}$ \\
\hline
\end{tabular}


Розподіл країн на 5 кластерів методом К-середніх

Таблиця 6

\begin{tabular}{|c|c|c|c|c|}
\hline $\begin{array}{c}\text { Members of } \\
\text { Cluster Number } 1\end{array}$ & $\begin{array}{c}\text { Members of Cluster } \\
\text { Number }\end{array}$ & $\begin{array}{c}\text { Members of } \\
\text { Cluster } \\
\text { Number } 3 \\
\end{array}$ & $\begin{array}{c}\text { Members of Cluster } \\
\text { Number } 4\end{array}$ & $\begin{array}{c}\text { Members of } \\
\text { Cluster } \\
\text { Number } 5\end{array}$ \\
\hline $\begin{array}{l}\text { Australia, Austria, } \\
\text { Belgium, } \text { China, } \\
\text { France, Germany, } \\
\text { Israel, } \\
\text { Korea, Japan, } \\
\text { Spain, } \\
\text { Kingdoysia, } \\
\text { United } \\
\text { USA }\end{array}$ & $\begin{array}{l}\text { Bulgaria, Chile, Cyprus, } \\
\text { Czechia, Estonia, Hungary, } \\
\text { Italy, Kazakhstan, Latvia, } \\
\text { Lithuania, Poland, } \\
\text { Portugal, Romania, } \\
\text { Russian Federation, Saudi } \\
\text { Arabia, Slovenia, Slovak } \\
\text { Republic }\end{array}$ & $\begin{array}{l}\text { Colombia, } \\
\text { India, } \\
\text { Indonesia, } \\
\text { Mexico, Peru, } \\
\text { Philippines, } \\
\text { South Africa, } \\
\text { Thailand }\end{array}$ & $\begin{array}{l}\text { Denmark, Finland, Hong } \\
\text { Kong, Iceland, Ireland, } \\
\text { Luxembourg, Netherlands, } \\
\text { New Zealand, Norway, } \\
\text { Qatar, Singapore, Sweden, } \\
\text { Switzerland, Taiwan, } \\
\text { United Arab Emirates }\end{array}$ & $\begin{array}{l}\text { Argentina, } \\
\text { Brazil, } \\
\text { Croatia, } \\
\text { Greece, } \\
\text { Jordan, } \\
\text { Turkey, } \\
\text { Ukraine }\end{array}$ \\
\hline
\end{tabular}

Джерело: розраховано авторами

При порівнянні результатів розподілу країн по кластерах із різною їх кількістю ми можемо зробити висновок, що склад двох кластерів залишився без змін, що відповідає найбільш розвиненим країнам світу (позначені у таблицях сірим кольором). Менш розвинені країни були розподілені на три кластери за ступенем їх економічного розвитку. При порівнянні різних методів кластеризації (табл. 3 і 5), ми можемо побачити, що збігається склад трьох кластерів, що відображають найбільш розвинені та країни із слабкими позиціями у рейтингу конкурентоспроможності. Країни у середині списку розподіляються по кластерах за ступенем їх економічного розвитку.

Разом $з$ тим, за результатами кластерного аналізу зберігається розподіл країн за територіальною й економічною подібністю, сутність якого полягає в тому, що країнисусіди мають схожі географічні умови та реалізують стратегії економічного розвитку, орієнтуючись одна на одну, тобто територіальний чинник має важливе значення при формуванні міжнародної конкурентоспроможності країн. Другим фактором подібності $\epsilon$ стратегії економічного розвитку країн.

Для обгрунтування цього висновку проведем повторний аналіз показників міжнародної конкурентоспроможності країн за методологією ІМД за показниками 2021 p. На рис. 5 представлено дендрограму як результат кластеризації 64 країн з рейтингу, побудованих за 20 розгорнутими факторами конкурентоспроможності.

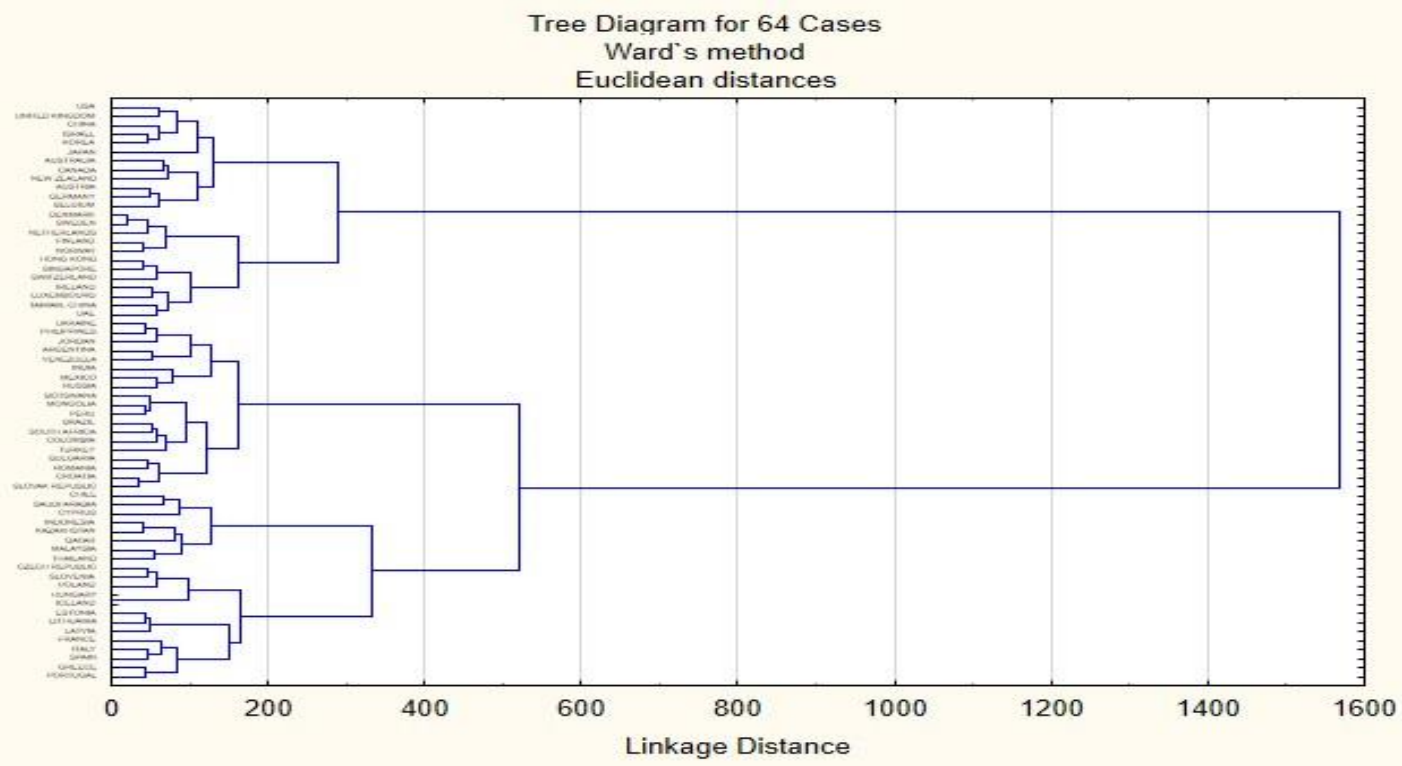

Рисунок 5. Дендрограма кластеризації 64 країн з рейтингу ІМД за показниками 2021 p. 
За характером гілок можна визначити п'ять кластерів країн відносно лінії розподілу, що відповідає дистанції в 200 одиниць. Наступним кроком ми проведемо кластерний аналіз методом к-середніх з розподілом результатів за п'ятьма кластерами (табл. 7).

Таблиця 7

Розподіл країн на 5 кластерів методом К-середніх

\begin{tabular}{|c|c|c|c|c|}
\hline $\begin{array}{c}\text { Members of Cluster } \\
\text { Number } 1\end{array}$ & $\begin{array}{l}\text { Members of } \\
\text { Cluster } \\
\text { Number } 2\end{array}$ & $\begin{array}{c}\text { Members of } \\
\text { Cluster } \\
\text { Number } 3\end{array}$ & $\begin{array}{c}\text { Members of } \\
\text { Cluster Number } 4\end{array}$ & $\begin{array}{l}\text { Members of } \\
\text { Cluster Number } \\
5\end{array}$ \\
\hline $\begin{array}{l}\text { Austria, Canada, China, } \\
\text { Denmark, Finland, } \\
\text { Germany, Hong Kong, } \\
\text { Ireland, Luxembourg, } \\
\text { Netherlands, New } \\
\text { Zealand, Norway, } \\
\text { Singapore, Sweden, } \\
\text { Switzerland, Taiwan, } \\
\text { UAE, United Kingdom, } \\
\text { USA }\end{array}$ & $\begin{array}{l}\text { Australia, } \\
\text { Belgium, } \\
\text { Czech } \\
\text { Republic, } \\
\text { Estonia, } \\
\text { France, Israel, } \\
\text { Italy, Japan, } \\
\text { Korea, } \\
\text { Lithuania, } \\
\text { Spain, Portugal }\end{array}$ & $\begin{array}{l}\text { Chile, India, } \\
\text { Indonesia, } \\
\text { Kazakhstan, } \\
\text { Malaysia, } \\
\text { Saudi } \\
\text { Arabia, } \\
\text { Thailand, } \\
\text { Qatar }\end{array}$ & $\begin{array}{l}\text { Bulgaria, Croatia, } \\
\text { Cyprus, Greece, } \\
\text { Hungary, Iceland, } \\
\text { Latvia, Slovak } \\
\text { Republic, } \\
\text { Slovenia, Turkey, } \\
\text { Russia, Romania, } \\
\text { Poland }\end{array}$ & $\begin{array}{l}\text { Argentina, } \\
\text { Botswana, } \\
\text { Brazil, } \\
\text { Colombia, } \\
\text { Jordan, Mexico, } \\
\text { Mongolia, Peru, } \\
\text { Philippines, } \\
\text { South Africa, } \\
\text { Ukraine, } \\
\text { Venezuela }\end{array}$ \\
\hline
\end{tabular}

Джерело: розраховано авторами

За результатами цього розподілу ми отримали по одному спільному кластеру 3 найсильнішими та слабкішими економіками, які представлені в рейтингу IMД 2021 р., а також три кластери з проміжним розподілом середньо розвинутих країн.

Отже, нами було використано два набори показників за 2019 і 2021 pp., за якими було отримано схожі результати кластеризації країн.

3 нього ми можемо зауважити, що кластер 1 має суттєві коливання у показниках цін і податковій політиці майже до кластеру 5, та випереджає всі кластери за іншими показниками. Всі інші кластери зберігають вказані пріоритети при розподілі середніх величин, хоча й мають деякі коливання, найбільші з яких припадають на стабільність цін внутрішнього ринку, стабільність державної фінансової та податкової політики, ринку праці, фінансового ринку, ціннісні фактори та практики управління.

У звіті 3 рейтинговими показниками конкурентоспроможності країн ІМД 2021 року зазначено, що ціннісні фактори та практики управління мали суттєве значення для подолання наслідків пандемії COVID-19, які вплинули на консолідацію державних зусиль і політики громад щодо позитивного вирішення багатьох проблемних питань. 3 2011 року Швейцарія конкурує 3 Сінгапуром за перше місце в рейтингу конкурентоспроможності ВЕФ, за рейтингом ІМД з 2016 року, проте наслідки пандемії більше вразили саме Сінгапур, оскільки він має більшу залежність від експорту й імпорту послуг та від мобільності людей, у тому числі бізнесового туризму, в результаті чого знизився його рейтинг в 2021 році.

Для Швейцарії та Норвегії, наприклад, склалась сприятлива ситуація під час пандемічних обмежень, з одного боку, через національну автономність, відсутність членства в Свропейському Союзі, а з іншого, внаслідок вільного доступу до спільного ринку товарів і послуг, який утворений в $Є С$, й який є одним із найбільших у світі. Така можливість клалась через певні обмеження у глобальних ланцюжках поставок різних категорій товарів від сировини до готової продукції. 
3 іншого боку, проведений аналіз дозволяє припустити, що позиції Китаю в рейтингах конкурентоспроможності будуть зростати, оскільки він потрапив до одного кластеру зі США, які визнають однією з найбільш конкурентоспроможних країн світу. Це можна пояснити державною політикою розвитку Китаю, орієнтованою на скорочення бідності, розбудову інфраструктури та системи освіти, які мають призвести в подальшому до зростання рейтингу його конкурентоспроможності.

Висновки. Оцінка рейтингів міжнародної конкурентоспроможності країн дозволила визначити, що вони дають співставні результати, що відображають наявний і перспективний потенціал національних економік. Також можна зробити висновок, що ЄС як значне інтеграційне утворення у світовій економіці посилює позиції на світовому ринку як провідних його учасників, так і незалежних економік, які орієнтуються на нього як найбільший регіональний ринок у світі; з іншого боку, середні та слабкі за економічним розвитком країни-учасники ЄС не посилили власних позицій у рейтингах, що залишає актуальним питання до пошуку шляхів їх подальшого зростання.

Проведений кластерний аналіз за різним набором показників показав сталу карту розподілу країн по п'яти кластерах, які визначаються ступенем економічного розвитку, 3 яких перші два кластери представлені високорозвиненими країнами світу, більшість 3 яких входить до об'єднання G-20. Однією з особливостей розподілу є розташування США і Китаю в одному сегменті за спільністю ознак, хоча за результуючими показниками останній відноситься до країн із середнім рівнем конкурентоспроможності.

Проміжний кластер представлений південними та східними країнами $€ C$, включаючи прибалтійські, а також розвиненими індустріальними країнами Азії. Заключні два кластери представлені країнами, які мали статус транзитивних, а в теперішній час характеризуються активним індустріальним розвитком. Відповідно, Україна має одну з слабких позицій у рейтингах, i завершує ранжування, разом із Аргентиною в одному сегменті.

Суміщення двох рейтингів міжнародної конкурентоспроможності країн свідчить, що вони відображають тісний зв'язок між ними (географічна подібність) й економічними стратегіями (потрапляння до одного сегменту у межах кластеру, наприклад, країни-експортери нафти; міста-країни; малі країни-острови; країни 3 найбільшими економіками у світі; скандинавські країни; прибалтійські країни).

Отже, за результатами кластерного аналізу визначено збіг розподілу країн за територіальною й економічною подібністю, сутність якого полягає в тому, що країнисусіди мають схожі географічні умови та реалізують стратегії економічного розвитку, орієнтуючись одна на одну, тобто територіальний чинник має важливе значення при формуванні міжнародної конкурентоспроможності країн. Другим фактором подібності $\epsilon$ стратегії економічного розвитку країн.

\section{СПИСОК ВИКОРИСТАНИХ ДЖЕРЕЛ}

1. Світовий економічний форум. URL: https://www.weforum.org

2. Інститут розвитку менеджменту URL:https://www.imd.org/researchknowledge/competitiveness/

\section{REFERENCES}

1. World Economic Forum (2021) Available at: https://www.weforum.org (accessed 25 August 2021).

2. International Institute for Management Development (2021) Available at: https://www.imd.org/research-knowledge/competitiveness/ (accessed 25 August 2021). 
Таранич А. В., Таранич О.В.

\section{ОЦЕНКА И СРАВНЕНИЕ МЕЖДУНАРОДНОЙ КОНКУРЕНТОСПОСОБНОСТИ СТРАН}

В работе раскрыты особенности определения международной конкурентоспособности стран в мировых рейтингах и оценены результаты их рейтингования.

Проведена оценка рейтингов международной конкурентоспособности стран за период с 2005 до 2019 гг., которая позволила определить, что они дают сопоставимые результаты, отражающие имеющийся и перспективный потенциал национальных экономик. Определено, что ЕС как значительное интеграционное образование в мировой экономике усиливает позиции на мировом рынке как ведущих его участников, так и независимых экономик, которые ориентируются на него как на крупнейший региональный рынок в мире; с другой стороны, средние и слабые по экономическому развитию страны-участники ЕС не усилили собственных позиций в рейтингах, что оставляет актуальным вопрос поиска путей их дальнейшего роста.

Проведен кластерный анализ по различным наборам показателей, что показал устойчивую карту распределения стран по пяти кластерам, которые определяются степенью их экономического развития. При совмещении двух рейтингов международной конкурентоспособности стран определено, что они отражают тесную связь между странами (географическая сходство) и экономическими стратегиями (попадание в один сегмент в пределах кластера, например, страны-экспортеры нефти; города-страны; малые страны-острова; страны с крупнейшими экономиками в мире; скандинавские страны; прибалтийские страны). По результатам кластерного анализа определено совпадение распределения стран по территориальному и экономической сходству, сущность которого заключается в том, что страны-соседи имеют схожие географические условия и реализуют стратегии экономического развития, ориентируясь друг на друга, то есть территориальный фактор имеет важное значение при формировании международной конкурентоспособности стран. Вторым фактором сходства являются стратегии экономического развития стран.

Ключевые слова: международная конкурентоспособность стран, мировые рейтинги конкурентоспособности, мировое хозяйство, кластерный анализ, COVID-19.

\section{Taranich A., Taranych O.}

\section{ASSESSMENT AND COMPARISON OF INTERNATIONAL COMPETITIVENESS OF COUNTRIES}

The paper reveals the specific features of determination of the countries' international competitiveness of in world rankings and evaluates the results of their ranking.

An assessment of the rankings of the international competitiveness of countries for the period from 2005 to 2019 was carried out. It made possible to determine that they have comparable results, reflecting the existing and prospective potential of national economies. It is determined that the EU, as a significant integration formation in the world economy, strengthens the positions in the world market of both its leading participants and independent economies, which are guided by it as the largest regional market in the world; on the other hand, the EU member states that are medium and weak in terms of economic development have not strengthened their own positions in the rankings, which leaves the question of finding ways of their further growth relevant.

A cluster analysis was carried out for various sets of indicators, which showed a stable map of the distribution of countries in five clusters, which are determined by the degree of their 
economic development. it was determined during combining two rankings of international competitiveness of countries, that they reflect a close relationship between countries (geographical similarity) and economic strategies (falling into one segment within a cluster, for example, oil exporting countries; city-countries; small island countries; countries with largest economies in the world; Scandinavian countries; Baltic countries). Based on the results of cluster analysis, the coincidence of the distribution of countries by territorial and economic similarity was determined, the essence of which is that neighboring countries have similar geographical conditions and implement strategies of economic development, focusing on each other, that is, the territorial factor is important in the formation of countries' international competitiveness. The second factor of similarity is the strategies of countries' economic development.

Key words: countries' international competitiveness, world competitiveness rankings, world economy, cluster analysis, COVID-19. 